\title{
Pengembangan Handout Mind Mapping Di MI (Materi Sholat Jum'at Mata Pelajaran Fiqih Kelas IV Kurikulum 2013)
}

\author{
Kurniatun Nailatin Fauziah 1, Siti Rofi'ah 2 \\ 1 PGMI, FAI, Universitas Hasyim Asy'ari, Indonesia \\ 2 PGMI, FAI, Universitas Hasyim Asy'ari, Indonesia
}

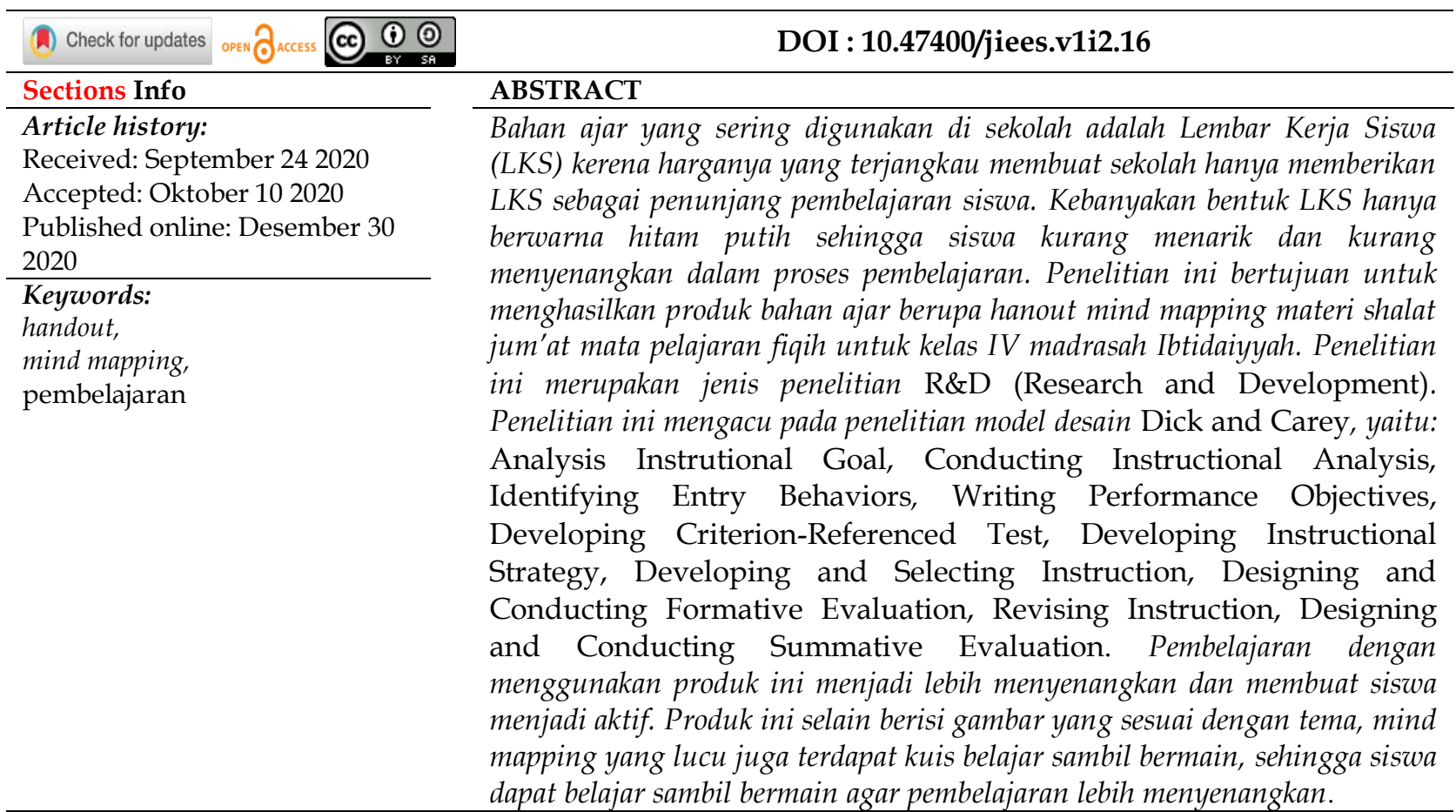

\section{INTRODUCTION}

Bahan ajar merupakan segala bahan (baik informasi, alat maupun teks) yang disusun secara sistematis. Berdasarkan penjelasan mengenai definisi bahan ajar tersebut maka, bahan ajar disusun menggunakan bahan-bahan dari berbagai macam sumber seperti buku, orang (pendidik atau narasumber), pesan, maupun lingkungan. Oleh karena itu, untuk menyusun sebuah bahan ajar, dibutuhkan adanya sumber bahan ajar atau sumber belajar. Salah satu bahan ajar yang paling mudah dan cocok digunakan dalam pembelajaran agar siswa tidak mudah bosan adalah dengan menggunakan Handout Mind Mapping.

Handout merupakan satu lembar atau beberapa lembar berisi materi, tes maupun tugas yang diberikan pendidik kepada peserta didik. Dengan kata lain, apabila pendidik membuat ringkasan suatu topic, petunjuk praktikum, lembar kerja siswa, maka keseluruhannya itu dapat dikategorikan sebagai handout. Penggunaan bahan ajar handout sendiri dapat diaplikasikan dengan mind mapping agar siswa menjadi semakin bersemangat dalam belajar.

Handout mind mapping sebaiknya dibuat dengan warna yang lucu disertai dengan gambar agar siswa lebih mudah memahami isi pelajaran. Hamdout mind 
mapping sangat cocok digunakan dalam pembelajaran terutama untuk anak sekolah usia dini SD/SMP.

Dalam penelitian ini akan membahas beberapa masalah antara lain menjelaskan bahan ajar handout mind mapping, mengembangkan bahan ajar handout mind mapping pada pembelajaran fiqih materi shalat jum'at.

Pengembangan adalah suatu usaha untuk meningkatkan beberapa kemampuan teknis, teoritis, konseptual, dan moral sesuai dengan kebutuhan melalui pendidikan dan latihan. Pengembangan adalah suatu cara mendesain pembelajaran secara logis, dan sistematis dalam rangka untuk menetapkan segala sesuatu yang akan dilaksanakan dalam proses kegiatan belajar dengan memperhatikan kemampuan dan penguasaan peserta didik.

Handout berasal dari bahasa Inggris yang berarti informasi, berita atau surat lembaran. Handout termasuk media cetak yang meliputi materi-materi yang disediakan di atas kertas untuk pembelajaran dan informasi belajar. Biasanya diambil dari beberapa literatur yang memiliki relevansi dengan materi yang diajarkan/kompetensi dasar dan materi pokok yang harus dikuasai oleh peserta didik.

Mind mapping atau yang biasa disebut dengan peta konsep ilustrasi grafis kret yang menerangkan bagaimana sebuah konsep tunggal dihubungkan ke konsep-konsep yang lain pada kelompok yang sama.

Pengembangan bahan ajar menggunakan handout mind mapping sangat cocok digunakan untuk siswa usia SD/MI. Menurut Piaget, pada usia 7-11 tahun anak mulai mampu meninggalkan egosentrisnya dan mulai bermain secara berkelompok dan senang bekerjasama. Anak juga sudah memahami tentang motivasi dan mampu berpikir secara runtut dan teratur. Hal ini juga sesuai dengan wawancara dengan guru mata pelajaran fiqih kelas IV di MI Al-Adnanni Kayangan, bahwasanya siswa mulai sering berkomunikasi dengan siswa yang lain secara berkelompok dan lebih senang belajar sambil bermain. Sehingga, pemakaian bahan ajar handout mind mapping sangat cocok digunakan untuk menggali rasa ingin tahu anak yang besar dan mengembangkan cara berpikir anak yang sistematis. Hal ini sesuai dengan penelitian yang telah dilakukan oleh Rini Sandika, dkk (2014) didapatkan hasil belajar pada mata pelajaran biologi pada materi Kingdom Protista lebih praktis dan valid dibandingkan dengan menggunakan bahan ajar yang telah digunakan sebelumnya.

Terdapat beberapa perbedaan antara penelitian yang dilakukan Rini Sandika dan penelitian sekarang . penelitian yang dilakukan oleh Rini Sandika merupakan pengembangan handout bergambar dilengkapi dengan peta konsep pada materi kingdom Protista untuk siswa SMA. Sedangkan, pengembangan handout mind mapping pada materi sholat jum'at untuk siswa kelas IV Madrasah Ibtidaiyyah.

Berdasarkan permasalahan diatas maka perlu adanya pengembangan handout mind mapping guna untuk menaikkan hasil belajar siswa. Tujuan penelitian dan pengembangan bahan ajar handout mind mapping ini adalah untuk menjelaskan hasil pengembangan bahan ajar, untuk mengembangkan bahan ajar menurut validator dan uji respon siswa di kelas IV MI Al-Adnani Kayangan Diwek Jombang. 


\section{RESEARCH METHOD \\ Jenis Penelitian}

Penelitian ini merupakan jenis penelitian R\&D adalah metode penelitian yang untuk menghasilkan produk tertentu, dan menguji keefektifan produk tersebut. Produk yang akan dihasilkan dalam penelitian ini berupa handout mind mapping materi Shalat jum'at mata pelajaran fiqih untuk siswa SD kelas IV. Subjek yang ada dalam penelitian ini adalah guru dan siswa kelas IV MI Al-Adnani Kayangan Diwek Jombang.

Jenis penelitian yang digunakan adalah model pengembangan pembelajaran Walter Dick and Lou Carey. Pada model Dick and Carey terdapat 10 tahapan desain pembelajaran tetapi pada model pengembangan ini hanya digunakan 9 tahapan. Hal ini dilakukan dengan pertimbangan bahwa pengembangan bahan ajar yang dilakukan hanya sebatas pada uji coba prototipe produk. Tahapan kesepuluh (Evaluasi Sumatif) tidak dilakukan karena berada di luar proses pembelajaran, sehingga dalam pengembangan ini tidak digunakan.

Tahapan-tahapan itu diantaranya adalah Analysis Instrutional Goal, Conducting Instructional Analysis, Identifying Entry Behaviors, Writing Performance Objectives, Developing Criterion-Referenced Test, Developing Instructional Strategy, Developing and Selecting Instruction, Designing and Conducting Formative Evaluation, Revising Instruction, Designing and Conducting Summative Evaluation.

Kegiatan analisis tujuan umum pembelajaran, peneliti mengidentifikasi berbagai hal terkait dengan kondisi riil di lapangan, di kelas, di sekolah atau latar lainnya. Peneliti mencatat segala keadaan yang dinilai belum memadai untuk memenuhi kebutuhan belajar, sehingga bisa menemukan dampak yang menyebabkan kurang maksimalnya hasil belajar siswa. Faktanya penggunaan bahan ajar yang diberikan sekolah membuat siswa bingung dan hasil belajar siswa banyak yang menurun.

Setelah identifikasi tujuan pembelajaran, selanjutnya adalah menentukan langkah yang dilakukan agar tujuan pembelajaran tercapai. Proses analisis pembelajaran pada akhirnya akan menentukan entry behavior (perilaku awal/masukan) yaitu pengetahuan, keterampilan, dan sikap yang diperlukan oleh siswa untuk memulai pembelajaran.

Analisis mengenal tingkah laku masukan dan karakteristik siswa bisa dilakukan secara serentak bersamaan dengan analisis pembelajaran di atas, atau dilakukan secara analisis pembelajaran. Menganalisis peserta didik dan konteks, yang mencakup kemampuan, sikap, dan karakteristik awal peserta didik dalam situasi pembelajaran.

Siswa dalam penelitian ini merupakan siswa kelas IV yang berusia rata-rata 10-11 tahun dengan beberapa karakteristik. Menurut Piaget, pada usia 7-11 tahun anak mulai mampu meninggalkan egosentrisnya dan mulai bermain secara berkelompok dan senang bekerjasama. Anak juga sudah memahami tentang motivasi dan mampu berpikir secara sistematis. Kelas yang akan dijadikan penelitian termasuk kelas heterogen, yakni antara siswa berkemampuan tinggi, sedang dan rendah adalah seimbang. 
Sesuai dengan penelitian yang telah terlaksana, maka peneliti menyajikan data yang telah berhasil dikumpulkan di lapangan yakni dengan data kualitatif dan kuantitatif.

Data kualitatif juga berasal dari saran dan pendapat para validator yang diberikan pada saat memvalidasi bahan ajar handout sebagai acuan untuk kelayakan pengembangan yang sedang dilakukan oleh pengembang. Sedangkan data kuantitatif dalam penelitian ini berasal dari angket para validator, angket guru dan siswa serta penilaian hasil belajar siswa yang akan dipaparkan.

Namun sebelumnya akan dijelaskan terlebih dahulu kriteria penskoran nilai dari angket penilaian yang menggunakan skala Likert.

Setelah data angket dikonversi ke dalam data berupa nilai berdasarkan tabel tersebut, langkah selanjutnya adalah menentukan rata-rata skor. Rata-rata pernyataan angket dengan skala likert, adalah;

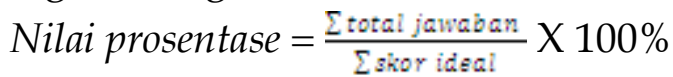

$$
P=\frac{\sum x}{\sum x i} X 100 \%
$$

Hasil presentase kemudian diinterpretasikan berdasarkan skala kategori keefektifan sebagai berikut: Kualifikasi Tingkat Kelayakan Berdasarkan Presentase.

Tabel 1. Tingkat Kelayakan

\begin{tabular}{ccc}
\hline Persentase $(\%)$ & Tingkat Kevalidan & Keterangan \\
\hline $84 \%<$ skor $\leq 100 \%$ & Sangat Valid & Tidak Revisi \\
$68 \%<$ skor $\leq 84 \%$ & Valid & Tidak Revisi \\
$52 \%<$ skor $\leq 68 \%$ & Cukup Valid & Revisi Sebagian \\
$36 \%<$ skor $\leq 39 \%$ & Kurang Valid & Revisi \\
$20 \%<$ skor $\leq 36 \%$ & Sangat Kurang Valid & Revisi \\
\hline
\end{tabular}

\section{RESULTS AND DISCUSSION}

Hasil produk pengembangan yang dikembangkan berupa Bahan Ajar Handout Mind Mapping dengan materi Sholat Jum'at. Adapun deskripsi dari produk bahan ajar Handout Mind Mapping ini adalah sebagai berikut:

Bentuk fisik : Bahan Cetak, Judul: Handout Mind Mapping Sholat Jum'at untuk Kelas IV SD/MI, Materi: Sholat Jum'at, Sasaran: Siswa kelas IV MI Al-Adnani Kayangan, Nama Pengarang: Kurniatun Nailatin Fauziah, Tebal Halaman: $2 \mathrm{O}$ halaman + ii, Cetakan : Pertama, Ukuran Kertas: A5 (210 x 148 mm).

Bagian sampul dalam Handout Mind Mapping dengan materi Sholat Jum'at memiliki 2 bagian yakni sampul depan dan sampul belakang. Cover depan Handout Mind Mapping terdiri dari nama penyusun, judul handout yang disesuaikan dengan pokok bahasan yang dikembangkan berjudul "Handout Mind Mapping materi sholat jum'at untuk kelas IV", background disesuaikan dengan isi materi yang ada dalam buku. 


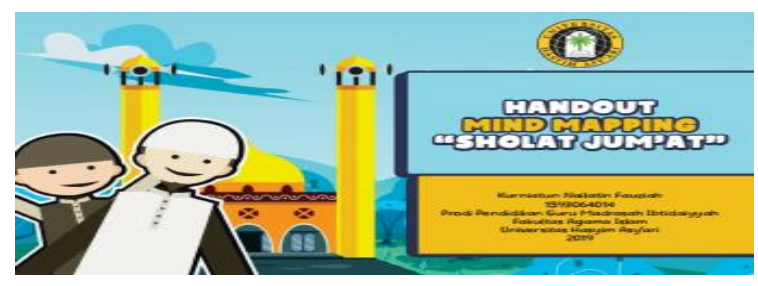

Gambar 1. Cover depan

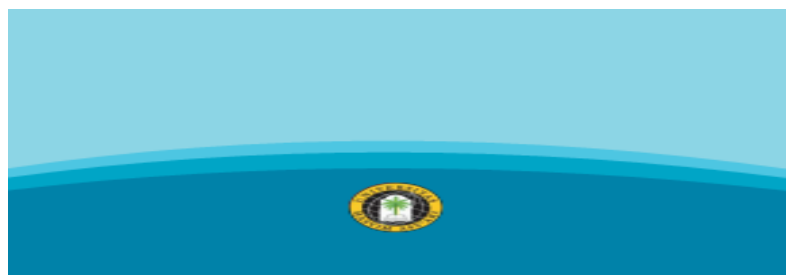

Gambar 2. Cover Belakang

Kata pengantar ditempatkan pada halaman awal buku sebagai pembuka komunikasi penulis dengan pembaca. Isi dari kata pengantar adalah upaya penulis untuk berkomunikasi dengan pembaca, dengan menerapkan beberapa prinsip.

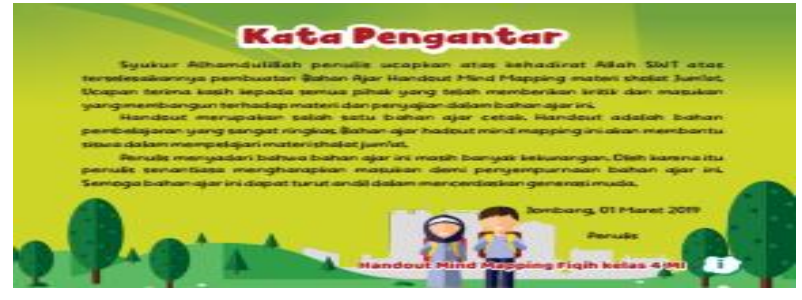

Gambar 3. Kata Pengantar

Daftar isi berisi bab pembelajaran yang akan dibahas pada halaman isi dan disertakan daftar halaman dari seluruh bagian pembelajaran yang terdapat dalam handout agar pembaca dengan mudah menemukan pokok bahasan yang dicari.

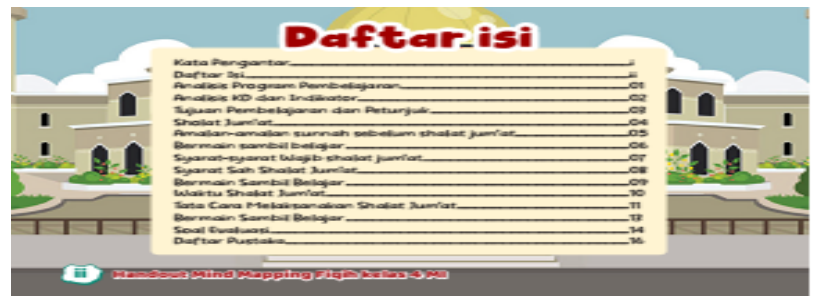

Gambar 4. Daftar Isi

Materi pembelajaran berisi materi yang sudah ditentukan sesuai dengan Kompetensi Dasar, indikator dan tujuan pembelajaran dengan harapan guru dan siswa dapat mengetahui hasil yang diperoleh. Selain itu terdapat materi pembelajaran singkat mengenai sholat jum'at mulai dari pengertian, syarat wajib, syarat sah, hal-hal sunnah yang dilakukan sebelum melaksanakan shalat jum'at serta tata cara melaksanakan shalat jum'at. 


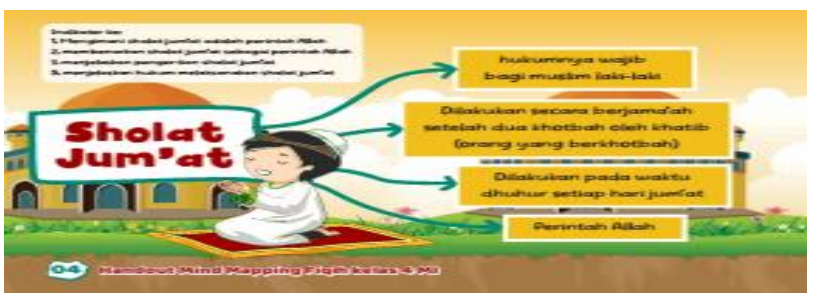

Gambar 5. Materi

Belajar sambil bermain merupakan evaluasi ringan sekaligus permainan sehingga anak-anak dapat mengerjakan soal tanpa berfikir dengan sangat serius. Pada bagian ini diaplikasikan dengan TTS (Teka-Teki Silang), mencari jejak dan menjodohkan tata cara melaksanakan shalat jum'at.

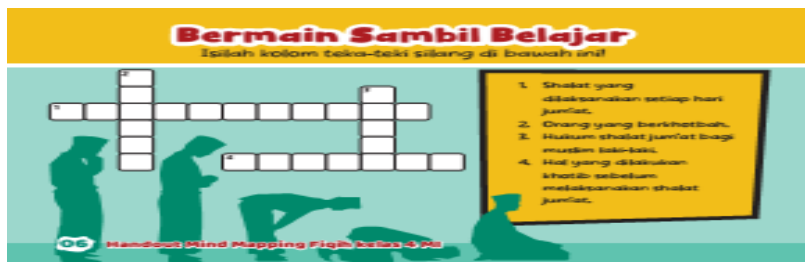

Gambar 6. Bermain Sambil Belajar

Evaluasi pembelajaran berisi tentang soal yang dapat dijawab secara singkat. Sehingga siswa dengan mudah menjawab pertanyaan yang sifatnya seperti permainan.

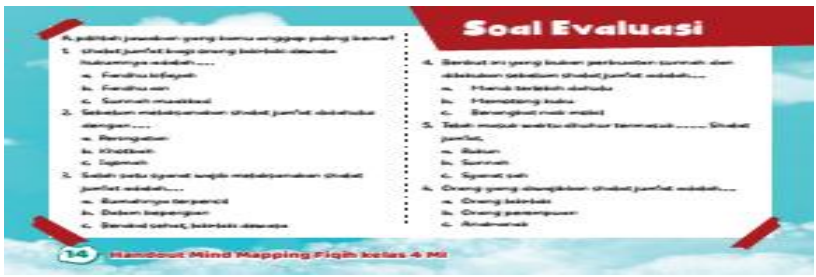

Gambar 7. Evaluasi

Daftar pustaka berisi referensi bahan bacaan yang relevan dengan materi Fiqih yang ada dalam bahan ajar.

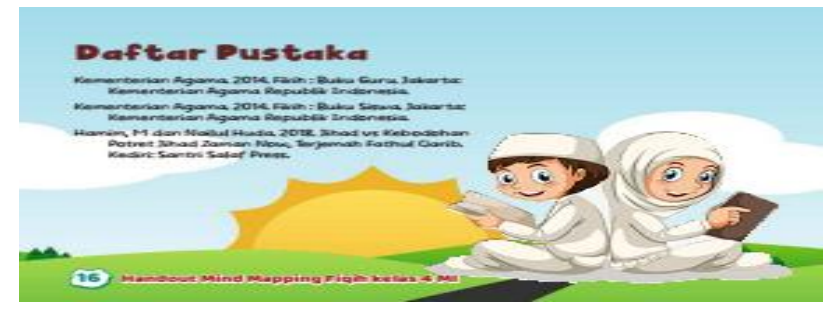

Gambar 8. Daftar Pustaka

Data yang terkumpul berupa data kualitatif dan kuantitatif. Data kualitatif berasal dari observasi di kelas yang dilakukan oleh peneliti dan juga wawancara dengan guru wali kelas IV MI Al-Adnani Kayangan. Secara singkat, dari hasil data kualitatif ini adalah terkadang peserta didik merasa jenuh dan tidak memiliki semangat tinggi dalam proses pembelajaran Fiqih.

Hasil validasi tahap pertama ahli isi/materi bahan ajar ini mencapai $85 \%$. Jika dicocokkan dalam tabel kriteria maka hasil ini mencapai kriteria sangat valid atau sangat layak $(84 \%<$ skor $\leq 100 \%)$. Validasi tahap pertama dianggap valid namun masih 
perlu ada perbaikan dalam beberapa hal diantaranya pada halaman 7 bahan ajar pokok bahasan sebaiknya diperbesar lagi font nya.

Hasil validasi tahap kedua ahli isi/materi bahan ajar ini mencapai 96\%. Jika dicocokkan dalam tabel kriteria maka hasil ini mencapai kriteria sangat valid atau sangat layak $(84 \%<$ skor $\leq 100 \%)$. Validasi tahap pertama dianggap valid. Sehingga dapat dijadikan salah satu rujukan dalam proses pembelajaran.

Hasil validasi tahap pertama ahli desain bahan ajar mencapai 76\%. Jika dicocokkan dalam tabel maka hasil ini mencapai kriteria valid atau layak $(68 \%<$ skor $\leq$ $84 \%$ ). Validasi tahap pertama dianggap valid namun masih perlu ada perbaikan pada beberapa bagian bahan ajar yakni pada bagian cover dan penempatan tulisan daftar isi.

Hasil validasi tahap kedua ahli desain bahan ajar mencapai $84 \%$. Jika dicocokkan dalam tabel kriteria maka hasil ini mencapai kriteria sangat valid atau sangat layak $(84 \%<$ skor $\leq 100 \%)$. Validasi tahap pertama dianggap valid. Sehingga dapat dijadikan salah satu rujukan dalam proses pembelajaran.

Hasil validasi tahap pertama ahli pembelajaran yakni guru yang mengajar fiqih kelas IV di MI Al-adnani mencapai 88\%. Jika dicocokkan dalam tabel kriteria maka hasil ini mencapai kriteria sangat valid atau sangat layak $(84 \%<$ skor $\leq 100 \%)$. Validasi tahap pertama dianggap valid namun masih perlu ada perbaikan pada beberapa bagian bahan ajar yakni pada bagian bahan ajar halaman 7 untuk pokok pembahasan dalam penggunaan font terlalu kecil sehingga harus diperbesar lagi.

Analisis kemenarikan siswa tahap pertama pada uji coba lapangan kelompok kecil mencapai $89 \%$. Berdasarkan perhitungan di atas maka diperoleh uji coba lapangan kelompok besar mencapai $88 \%$. Hasil yang diperoleh berdasarkan persentase dapat dikatakan bahwa bahan ajar sangat menarik. Hal ini dilihat dari tabel kualifikasi tingkat kemenarikan yaitu $(84 \%<$ skor $\leq 100 \%)$ dengan keterangan tingkat kemenarikan adalah sangat menarik.

\section{CONCLUSIONS}

Proses pengembangan bahan ajar handout mind mapping fiqih diawali dengan melakukan observasi dan wawancara kepada guru kelas IV Madrasah Ibtidaiyyah AlAdnani Kayangan, melakukan identifkasi Kompetensi Inti dan Kompetensi Dasar, mengumpulkan materi-materi yang berkaitan dengan shalat jum'at kemudian dicetak, diuji coba lapangan kepada siswa kelas IV, dan yang terakhir penyempurnaan produk dari hasil uji coba dan revisi para ahli.

Validator ahli isi/materi mencapai 96\% yang mempunyai kualifikasi valid. Validator ahli desain mencapai $84 \%$ yang mempunyai kualifikasi valid.Validator ahli pembelajaran guru mata pelajaran fiqih memperoleh kevalidan mencapai $88 \%$ yang mempunyai kualifikasi valid. Uji coba lapangan terhadap siswa mencapai $88 \%$ yang memiliki kualifikasi valid.

\section{ACKNOWLEDGEMENTS}

Penulis mengucapkan terima kasih yang sebesar-besarnya kepada PGMI, FAI, Universitas Hasyim Asy'ari Indonesia atas dukungan dan bantuan dalam menyelesaikan jurnal penelitian ini. 


\section{REFERENCES}

Kemendikbud. 2013. Peraturan Menteri Pendidikan dan Kebudayaan No 65 Tahun 2013 tentang Standar Proses. Jakarta: Kementerian Pendidikan dan Kebudayaan.

Kementrian Agama, Fikih:Buku Guru, (Kementerian Republik Indonesia, Jakarta, 2014), hlm 44 .

Majid, Abdul. 2010. Perencanaan Pembelajaran. Remaja Rosydakarya: Bandung.

Mohamad, Nur. 2018. Pengembangan Bahan Ajar, Dostock.com, diakses tgl 13 Oktober.

Pendis Kemenag. http://pendis.kemenag.go.id/index.php?a=detilberita\&id=8853, diakses 5 Nopember 2018.

Prastowo, Andi. 2015. Panduan Kreatif Membuat Bahan Ajar Inovatif; Menciptakan Metode Pembelajaran yang Menarik dan Menyenangkan. Diva Press:Jakarta.

Sandika, Rini dkk. 2014. Pengembangan Handout Bergambar Dilengkapi Peta Konsep Pada Materi Kingdom Protista Untuk Siswa SMA. E Jurnal; Sekolah Tinggi Keguruan dan Ilmu Pendidikan (STKIP) PGRI Sumatera Barat. http://jim.stkip-pgrisumbar.ac.id/prodi/ND?page $=22$

Taseman, Iman Rasiman, Arumi Puji Lestari, Atik Anturichana, Hanyfa Maulidiyah, H. H. (2020). IMPLEMENTASI EVALUASI SOAL PEMBELAJARAN IPS THE IMPLEMENTATION OF LEARNING EVALUATION ON SOCIAL STUDIES BASED ON 2013 CURRICULUM AT MI ASSYAFI' IYAH. AULADUNA: Jurnal Pendidikan Dasar Islam, 7(1), 74-80

Taseman. (2020). Pemanfaatan Media Visual Pada Pembelajaran IPS Di MI Darul Mutaallimin Sidoarjo. BADA' A: Jurnal Ilmiah Pendidikan Dasar, 2(1), 86-97.

Wahab, Rohmalina. 2016. Psikologi Belajar. Rajawali Press:Jakarta.

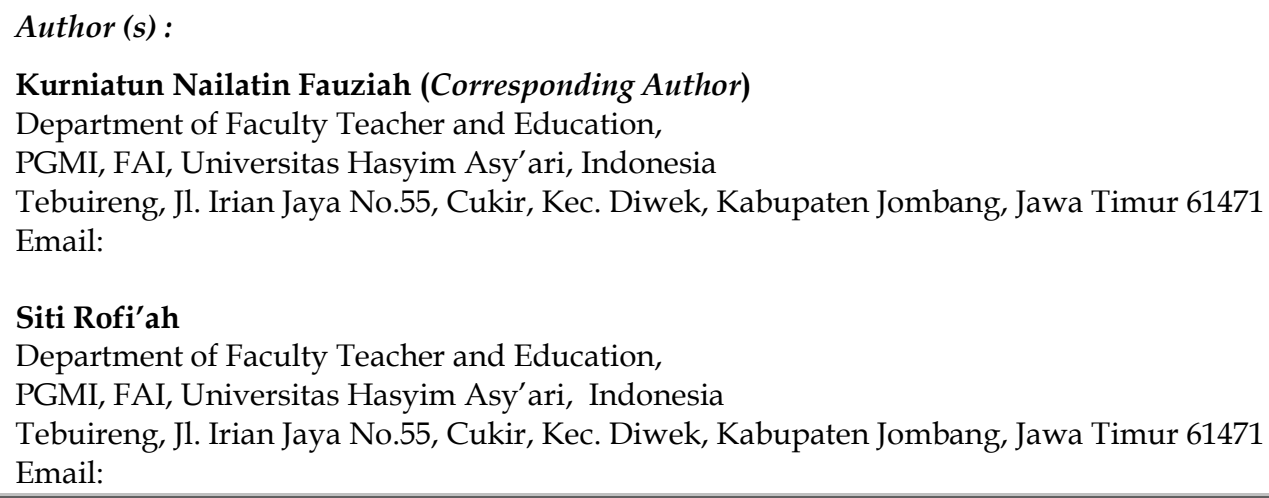

